\title{
Whither Business History? Memory, Message and Meaning
}

\author{
David Merrett ${ }^{1}$
}

\section{Introduction}

I started my Bachelor of Economics at Monash University in 1963. My arrival intersected the publications of Noel Butlin's two seminal pioneering works, Australian Domestic Product (1962) and Investment in Australian Economic Development, 1861-1900 (1964). Of course, I had no idea at the time how Noel's work, and the discipline of Australian economic history he created almost single-handedly, would shape my professional life. I was one of the lucky ones who found gainful employment in the burgeoning departments of economic history that sprang up in so many universities. While I never worked at ANU, I met Noel on many occasions. All of us in the field were drawn to Canberra for conferences and seminars, and to use the wonderful collection of records at the Noel Butlin Archives Centre (NBAC).

The question I want to explore is the future of archives, such as the NBAC and the one at my own university. My broad point is that the supply of business history and the demand for it by corporates have changed significantly in the past few decades. The most pessimistic interpretation is that the changing practice of business history within universities and the increasing reluctance of business to permit independent 'outsiders' access to their records bodes ill for specialist archives.

1 University of Melbourne,dtm@unimelb.edu.au. The paper is a revised version of the 14th annual Friends of the Noel Butlin Archives Centre Lecture for 2015. The author is indebted to two referees and the editor for their helpful suggestions. 
Let me start with a paradox. More and more is being written about 'business', but the work of researchers, whom we might describe as business historians drawing on archival material, is situated on the margins of this avalanche. What scholars write tends, with some notable exceptions, to be read only by other business historians. Telling stories about business that reaches a mass audience is done by others, most notably by journalists and critics of various hues, and this information reaches its audience through a variety of media. Archives holding extensive records relating to individual firms will be less useful to those current and future scholars working in a shifting paradigm of 'business history'. A recent paper by de Jong, Higgins and van Driel in Business History showed that only around 20 per cent of the articles published in the leading business history journals from 1970 to 2012 were written about a firm! Moreover, I fear that in the current climate and foreseeable future it will be harder to persuade companies to donate their records to archives that mandate the independence of scholars using them.

My argument progresses in a number of steps. First, I want to discuss the changes in what I call the 'practice' of business history that lessen the demand from academic practitioners for access to comprehensive archival material. Second, I want to suggest that firms today are less likely to make over their records for scholarly analysis than they were a generation or so ago. I will conclude by suggesting that the tide may yet turn back to the commissioning of full-blown histories.

\section{The practice of business history}

The practice of business history - the questions raised, the methodologies employed by authors, and type of records used - has changed over time in several significant ways. These changes have equally important implications for the fate of specialist archives holding 'whole of firm' records. The first dramatic shift could be placed shortly after the Second World War when Charles Wilson, a Fellow of Jesus College, Cambridge, produced his seminal The History of Unilever: A Study in Economic Growth \& Social Change (1954), which broke away from the interpretations of an earlier generation of largely amateur authors, family members and long-serving employees whose work he rather condescendingly described as 'heroic mythology'. In one sense Wilson was right, as these authors lacked the technical skills of the professional historians and, most likely, employed a good deal of self-censorship in the construction of their narratives. We learnt more about successful firms than the much larger group of those that had failed. 
Business history written by professional scholars boomed after the Second World War, feeding on a growing willingness of leading companies to tell their stories, opening their own archives to researchers or by donating records to external archives. Universities trained and employed scholars working in the field, primarily in economic history departments. Business history emerged as a vigorous sub-discipline, with its specialist journals and professional organisations. It is worth reminding ourselves that the Australian Economic History Review began life as Business Archives and History (1962-66).

The practice of professional business history, as described by Geoff Jones and Jonathon Zeitlin in their edited volume The Oxford Handbook of Business History (2003), rested on two fundamental foundations: first, that the author has access to the firm's confidential archives; and, second, that the author has complete independence in the construction of the narrative. Stories about the progress of a firm shifted beyond genealogy and hagiography. Scholars drew upon a wide range of records: correspondence, minutes of meetings, financial accounts, technical drawings, patent applications, court records, personnel records, and so on, to observe entrepreneurship and decision-making in real time, and also to place these businesses in a wider economic and social context. Business history was the weft to the warp of the fabric of economic history.

The work of one man, Alfred Chandler, recast the agenda for business history by taking us away from the study of individual firms. Chandler's big questions shifted the discipline. He provided an explanation for the rise of the large industrial enterprise in the United States, and later extended his research to Europe and Japan. He also showed that large firms tended to grow in a series of sequential steps: becoming large through vertical and horizontal integration, followed by diversification of product and market, from regional to national and multinational. The progress of growth required corresponding changes in the firm's organisational structures.

Chandler's work was a major conceptual breakthrough that captured the attention of scholars in other academic disciplines, most notably 'management'. Chandler demonstrated how teams of professional managers, rather than the founding families, determined a firm's long-term success. These ideas resonated with those being developed in the 'strategy' literature - the resource-based view in which firms are described in terms of their resources and capabilities. Moreover, management consultants leapt into the breach by showing firms how to reorganise their administrations as they recast strategies.

The scale, complexity and dynamism of firms has made writing business history more challenging. More recently, the ownership of all or part of an organisation is often impacted by mergers and acquisitions, and by divestment of parts of the firm. The portfolio of products and activities was regularly rebalanced. 
The countries and towns in which firms produced, undertook R\&D and sold their wares differed from decade to decade as firms internationalised in response to globalisation. The ethnicity of management and the workforce shifted accordingly, as operations spread across the globe.

Consider the case of BHP Billiton, an iconic Australian firm: it has not had an Australian national as CEO since 1998; just half of its workers are in Australia; two of its divisions, petroleum and copper, have their headquarters outside Australia; over 80 per cent of its shares are held by footloose institutional investors; it operates with many foreign partners in joint-ventures; and it is said not to pay much tax in this country. The original name of the company was linked to a place; its lead, silver and zinc mines at Broken Hill in western New South Wales. The nature of the company's business altered, from miner to steelmaker around 1912, but it still called Broken Hill home. The connection between place of origin and what it did was broken as BHP became a global resources company, having merged with Billiton in 2001. Billiton began life in 1860 as a Dutch mining house operating in Indonesia. It was acquired by Royal Dutch Shell in 1970 and then sold to the South African miner Gencor in 1994 who listed its subsidiary on the London Stock Exchange before divesting it in 1997. Its locally based Australian steel business was spun off as BlueScope in 2002. A further reshaping of the global portfolio of activities led to another demerger in 2015, spinning off a host of what are described as 'assets' bundled together in a free-standing operation called South 32, not a place but a latitude.

Business historians have been faced by another challenge. As the specialist fields within management expanded, drawing on the core disciplines of sociology, psychology and economics, generalist historians have struggled to develop mastery of them all. The numerous histories commissioned by Unilever demonstrate the point: Wilson's first book took two volumes to cover the period from 1851 to 1945 . It is organised chronologically. The second volume, Unilever 1945-1965: Challenge and response in the Post-War Industrial Revolution (1968), covers a shorter period, 20 years, and is divided into an examination of a chronology and, perhaps anticipating Chandler, examined the organisational response to changing strategies. Unilever's foreign operations were so diverse and important that they required a separate telling: by David Fieldhouse in Unilever Overseas; the Anatomy of a Multinational (1978). In 2005, Geoffrey Jones published his version - Renewing Unilever:Transformation and Tradition - which took the story up to 1990. Like Wilson, he combines narrative and a series of examinations about particular issues such as branding and marketing, innovation, acquisitions and divestments. These topics are pursued in greater depth than attempted by his predecessors. Advances in management and marketing theory have increased our understanding of how business operates, 
but few authors would possess the requisite knowledge of a diverse range of topics to satisfy a professional readership. Jones produced an exceptional history, aided by a team of assistants whose research was focused on specialist areas.

A new genus of business historian subsequently entered the field who greatly outnumber the previous occupants. These were employed in business schools rather than departments of economic history. Jones and Zeitlin describe them as scholars who study the historical development of businesses but who may or may not use archival records. Their contribution has been to transfer new theoretical perspectives and conceptual frameworks into the field. Business history, especially in its leading journals, now borrows heavily from other social sciences for its questions and solutions. Narratives without a theoretical compass are out of favour.

The contemporary needs of those studying business, and of business schools teaching fee-paying students how to run successful businesses, meant that business history assumed a new purpose: to instruct best practice from the 'lessons' of history. The lens of the authors catering for this market differed sharply from the grand histories of single firms. Teachers and students want upto-date business cases. Understanding the present matters more than a wholeof-life narrative of a firm. Moreover, most cases cover only a 'fragment' of a firm's history. They are usually brief, and few seek access to confidential archival material. Many use interviews with current staff. Nearly all rely heavily on publicly available information, the press and analysts' reports. Moreover, many of these teaching cases are 'theory confirming', providing a single illustration to verify what the management literature currently believes; for example, that most M\&As destroy shareholder value, or most joint ventures fail.

Chandler's single unifying idea has been replaced by multiple research agendas that increase the options available to authors in deciding what type of stories to tell. The most recent issue of Business History has a special issue entitled 'new business history' that calls on the discipline to adopt the research methodologies of the social sciences by 'develop[ing] theory and test[ing] hypotheses'. Scholars have already turned their attention to topics beyond the firm: studying industrial districts and clusters, trade associations and business groups. Moreover, the developing world has different business structures, family-owned conglomerates and state-owned firms, which challenged Western ideas about the conduct of business. Globalisation, in particular the shift of manufacturing to lower-wage-cost economies, led to a transformation of many Western firms. The boundaries of the firms became porous as they outsourced activities overseas and worked with local providers. More and more firms became multinationals, including service firms, and/or worked as partners in global supply chains. Operating in challenging foreign environments stimulated 
study of firm-host government relations. The diversity of national environments and types of business organisations fractured the US-centric version of what a modern firm was and how it behaved.

Academic business historians have responded to the changing pattern of demand for their services. Teaching the increasing numbers of business school students has fuelled a bonanza for case writing. As I shall discuss in a moment, firms are less willing to commission histories. Learned monographs tracing the history of a firm over the whole of its life, or at least a substantial length of time, have fallen from favour, not the least because universities give greater rewards to publication in $\mathrm{A}^{*}$ journals. The expanding disciplines of management and marketing have provided new tools for business historians who are deployed in writing papers for specialist journals. Theory trumps empiricism in those pieces published in journals such as Business History, Business History Review and Enterprise \& Society.

\section{Disclosure: Memory and message}

Why have some firms kept or handed their complete records to an archive and then asked or permitted someone to write their history?

Many of the classic studies in business history were commissioned by firms. Charles Wilson's book referred to earlier is one of the best examples of this genre. In his preface, Wilson tells us that the directors of Unilever had decided that:

... it would be useful to have an objective history showing how their particular business came to be what it is today. Besides serving as a reference work for the Company, itself, such an account might (they felt) contribute towards a better understanding of the nature of business in the academic world and elsewhere.

Unilever threw open its comprehensive records to an independent scholar, confident that the resulting story would reflect well upon itself.

Will today's business historians have the same access and freedom to write about the transformative companies of the twenty-first century: the Apples, Googles, Walmarts, Facebooks, and so on? What of Australia's leading companies? As importantly, will those firms keep sufficient records - hard copy and digital - that will permit an author to unravel or construct the 'story' in any depth?

My intuition is that the answer to both questions is 'No'. Let me argue my case with reference to Australia. Around the middle of the twentieth century, Australian firms had very different connections with the community in which they operated than do the shareholder-value driven firms of today. Geoffrey Blainey marvelled in the preface to his Gold and Paper: A History of the 
National Bank of Australasia (1958) that it is no light matter for a bank to open its records to an outsider and ask for a history which is "fairly and truly presented"'. The publication of this admirable book coincided with the bank's centenary. We can guess at the motivation. There was real sense of pride in lasting so long and having built a large business. The bank's balance sheet and its sense of importance grew hand in hand as it drew on an internal narrative of having been a pioneering business that helped 'build' the country and survived through the challenges of the 1890s banking crisis and bank nationalisation. Like the directors of Unilever who wanted the public to see how this 'particular business came to be what it is today', those at the National felt that such a story would reflect well upon them.

We should not gild the lily about the willingness of Australian firms to share their secret past with the world. While firms did contribute to 'development', they were also engaged in conflict with their workers over wages and conditions and with their consumers as anti-competitive behaviours pushed up prices. Some firms drew back from having their commissioned histories published. Imperial Chemical Industries of Australia and New Zealand (ICIANZ) did not publish Blainey's history of the company when it received his manuscript in 1959. Neither did Dalgety publish Max Hartwell's history of that firm, the manuscript of which can be found in the Noel Butlin Archives Centre.

Despite the point made above, my sense is that those firms operating over the century before the 1960s and 1970s may have been more anxious to have had their histories written by an independent author than those in the twentyfirst century. It was an era when relations between business and what are now referred to as 'stakeholders' were less complicated. There was a stronger sense of connection with community. Firms grew by opening new factories, mines and shops rather than closing them or divesting some operations, or taking others overseas. In such an environment, firms, confident of their success, would be more prepared to open their records so that their achievements could be shared with a wider audience, an internal and external readership both of which had a connection with the firm.

For all its wealth and power, the Big End of Town in Australia has been in a defensive mindset since the 1970s. It has felt more threatened and under challenge over the past generation than throughout our history. To that end it employs lobbyists, consultants and PR firms to manage its image and defuse crises. Moreover, it relies on lawyers to advise on the possibility of litigation following disclosure of sensitive issues. 
Before the 1960s and 1970s, business was firmly linked to our shared understanding of our past. The unifying story about Australian experience in the nineteenth century and much of the twentieth century has been one of 'progress', 'nation building' and 'national development'; this last including notions of modernity and national security.

Relations between business and the community shifted in fairly profound ways from the 1970s onwards. The postwar economic miracle (1945-72) came to an end in the recessions and high inflation of the 1970s. The old model of doing business supported by tariffs and subsidies, and operating with regulated finance and labour markets, could no longer generate full employment and/or stable prices. Faith in the Keynesian intervention ebbed away, to be replaced by a new model - the market - that offered both choice and efficient resource allocation. The gift that business now gave to the community was to be shareholder value.

Business could no longer appeal to the old national narrative of 'development' and 'progress'. The lack of international competitiveness of manufacturing was cruelly exposed as tariffs fell. Firms cut local employment; some moved operations offshore to take advantage of lower wage costs elsewhere. Many of the foreign manufacturing firms that had made hay behind the tariff wall also closed their factories and, as tariffs fell, sent in goods made elsewhere. The mining boom of the late 1960s and the stock market and property boom of the late 1980s and early 1990s changed perceptions about business. These episodes revealed serious weaknesses in the operations of our securities markets, an ineffectual form of corporate governance and staggering incompetence and some illegality from firms large and small. Journalists had a field day exposing the follies of all involved.

In this changing environment, business sees less value to itself in permitting outsiders - business historians - access to its records. 'Memory' was the overriding impulse for the first wave of commissioned business histories: a pride in past achievements, an acknowledgement of the role of individuals and families in creating firms that served their communities and nation, a testament to ethical leadership and kind employers, and the importance of science and technology as handmaidens to a story of progress.

Firms currently are more concerned with managing the 'message'; a company history is a matter for the marketing or PR department. For many firms (and the consultants who advise them and, in many cases, write the volumes), the object of the exercise is image management. I know of books commissioned by two of Australia's largest corporations that have been abandoned in the past few years. Many more companies may have decided not to undertake such an exercise, especially if there is a risk that an independent author might uncover a skeleton in a closet. We have the current example of Qantas preventing the publication 
of Fighting Words by a former employee, Lucinda Holdforth. Firms simply want to manage what the world knows about them. From personal experience, I can attest that the contracts offered to independent researchers/authors are far more restrictive now than was the case 30 years ago.

The shareholder-value corporation is a different animal compared to the National Bank of Australasia in the 1950s. The influence of founding families in major corporations, with some notable exceptions such as the Murdochs, Packers, Pratts and Lowys, is reduced. Compared to a generation earlier, today's firms' directors and 'top management teams' have far shorter tenure than their predecessors. Senior managers may work for many different firms during their careers. Top executives and boards do not have the same emotional connection with the firm as the managers of yesteryear. Memory stretching back into the past matters less to such people.

Firms can refuse to commission histories, deny access to their information, and publish carefully managed 'messages' about themselves. However, they cannot stop people writing about them. Bridget Griffen-Foley's The House of Packer: The Making of a Media Empire (2000) shows that a work of great scholarship can be written without access to the subject's records or access to its people. It is unlikely that other authors will have such persistence or be able to find a subject whose activities produced such a rich set of documents from third parties, government inquiries, the courts, trade unions and so on.

Over the past three decades most of the books published about Australian business have exposed failure and folly, and most of them have been written by journalists. Books about the near-death experiences of banks, badly behaved insurance, timber and asbestos companies, and tales of failed and dishonest entrepreneurs fill the shelves of bookshops.

We recognise celebrity business people by their Christian names: Twiggy, Kerry, Gina, James, Clive and Nathan from the current crop; Bondy and Skase from an earlier age of excess. They are the subjects of best-selling biographies; you can choose between authorised and unauthorised versions. Some business stories become TV series, and the domestic lives of our billionaires and their warring children are fodder for the pages of daily newspapers and gossip magazines. James Packer, son of the colourful Kerry, has been filmed fighting one of his friends in a suburban street. The latest round of litigation over inheritances and exposure of murky deals between politicians and businessmen by the ICAC in New South Wales promises a bonanza for what Charles Wilson calls the 'economic crime club' genre. 


\section{Conclusion}

My gloomy story has important consequences for the managers of specialist archives holding business records. I am sure that they are well aware of the trends I have described. It is difficult to get firms to donate material and/or to permit open access. The preoccupation with image management has reduced the flow of commissioned histories and, in some cases, the independence of those authors. My fear is that firms may be less inclined to invest in preserving and maintaining their own records. There is more interest in the here and now than the past from an academic audience, the business schools and the wider public. An archive whose records connect to a world of over half a century ago, as does the University of Melbourne Archive, may suffer from increasing irrelevancy from those wanting the up to date.

I promised you at least a glimmer of hope. Nearly a decade ago, I addressed an audience of those people whose job it was to manage what the public knew about the workings and image of firms. I provided my explanation of why their clients felt so threatened, why these firms had lost faith in the power of 'memory' to deliver a positive message. Business had been increasingly seen as the bad guy from the 1970s onwards. At present, the media is full of reports of self-serving financial advisers and supermarket chains mistreating suppliers. We might imagine that the firms involved might not want to commission a fullblown history. However, firms can be persuaded that telling their story is of greater value than trivialising the message or retreating into silence. The world in which business now operates has been transformed by globalisation. There have been many losers and a new breed of winners. Firms have had to adapt to survive, often shedding activities and moving to new locations. It is better for Australia that many firms have survived and prospered than had they gone to the wall. The wider public might want to know how this was achieved.

Can business recapture the position it held for so long as a valued and trusted partner within the community? That it once did so resulted from its inclusion in powerful stories and myths about national identity. The challenge for business today is to tell a story about what it does that fits into a wider national story.

I suggested to my audience of PR gatekeepers that a better way forward would be to use the pioneering metaphor to describe their adaptation of the shock of globalisation, an extension beyond 'memory' to something redolent with 'meaning'. The old powerful story is about the taming of a continent, a story of going inland. What we need now is a story to make sense of Australia's place in a globalising world, a story of going out as exporters, partners in supply chains and as multinationals. Globalisation poses challenges to business and the community as great as those in the first stage of 'pioneering'. Then, we struggled to come to 
an understanding of a new continent, to cope with its distance, heat and lack of water - a story superbly retold in Don Watson's The Bush. Now, the challenges come from having to find ways to compete in the wider world. All the virtues of the old story are required now: determination, resilience, the ingenuity to make do with little, and an optimism that you will eventually succeed. Immigrants, individuals and multinationals play their part in developing the capabilities of domestic firms and industries. Venture capital and incubators are the new version of old stories of start-ups. Collaboration between government, scientific research institutions and business-building hubs, clusters and networks is another form of community building. The outcome of this engagement with the wider world matters to all Australians. The stories of national development and business can still be interwoven.

Am I hopelessly optimistic about business changing its mind about the value of business history? Possibly so. However, self-interest is a strong motivator. In a special report on family business in its 18 April 2015 issue, The Economist argued that one reason family firms have a competitive advantage over their public corporation rivals was because they 'have a better story to tell about themselves'. Customers connect more with long-lived family companies with whom they shared strands of personal memory of family and place. The Economist piece argued that "the more companies compete to sell "meaning" as well as mere products, the better family companies will do'. All firms can play this game. What better way to do it than to replicate the motivation of the directors of Unilever, to provide 'an objective history showing how their particular business came to be what it is today'? Full disclosure would pay higher returns than managing the 'message' into oblivion. 
This text is taken from Agenda, Volume 22 - Number 1, 2015, edited by William Coleman, published 2015 by ANU Press, The Australian National University, Canberra, Australia. 